\title{
Tectonically-controlled Late Triassic and Jurassic sedimentary cycles on a peri-Tethyan ridge (Villány, southern Hungary)
}

\author{
Attila Vörös \\ Research Group for Paleontology, Hungarian Academy of Sciences, \\ Hungarian Natural History Museum, Budapest
}

\begin{abstract}
The article briefly summarizes the history of research of the Villány Mesozoic, with a focus on the Templom-hegy at Villány, and gives short descriptions of the important outcrops of the area. The geologic sketch of the Templom-hegy and concise descriptions of the Upper Triassic Mészhegy Formation, the Pliensbachian Somssichhegy Formation and the Bathonian-Callovian Villány Formation are also given. Several sedimentary cycles were recognized in the early Mesozoic formations exposed on the Templom-hegy. From among them, three fluvio-lacustrine, fining-upward cycles in the Late Triassic and one (or possibly two), marine, fining and deepening upward in the Early Jurassic, are demonstrated and evaluated in detail. The Late Triassic and Early Jurassic cycles at Villány were deposited in a westward-tilted half-graben structure, where repeated tectonic movements were responsible for the episodic and cyclic nature of the sedimentation. The finingupward trends within the three cycles probably reflect climatic changes from humid to arid conditions. For the Middle Jurassic the paleotectonic regime changed: faulting ceased and the territory began to sink uniformly. The Mesozoic subsidence history of the Villány area has close analogies in the contemporaneous blocks of the European inner shelf domain (Helvetic, Briançonnais, (central Penninic, Czorsztyn), and High Tatric Ridges, and the Bihor Autochthon). Their shared features are intensive subsidence in the Early and Middle Triassic, followed by a long interruption of subsidence in the Late Triassic to Middle Jurassic, then a renewed, rapid subsidence in the Late Jurassic. The interrupted subsidence was accompanied by erosion and formation of half-grabens, starting from the mid-Triassic. From this time on, these areas belonged to a transpression/transtension dominated zone for nearly 70 million years, until the Middle/Late Jurassic opening of the ValaisMagura oceanic belt.
\end{abstract}

Key words: Triassic, Jurassic, sedimentary cycles, paleotectonics, subsidence history Villány, South Hungary

Address: A. Vörös: H-1083 Budapest, Ludovika tér 2, Hungary, e-mail: voros@nhmus.hu Received: February 18, 2010; accepted: April 7, 2010 


\section{Introduction}

The range of the Villány Hills is built up by north-vergent tectonic thrust sheets (or nappes) (Fig. 1). In these (at least five) thrust sheets one can recognize the repetition of dominantly carbonate successions of Middle Triassic to Lower Cretaceous age, dipping $40-80^{\circ}$ to the south. The Villány Hills provide one of the best-studied surface outcrop regions of the Villány-Bihor Zone of the Tisza Terrane (Kovács et al. 2000; Haas 2001; Csontos and Vörös 2004; Vörös and Csontos 2006a). On the basis of the tectonic analysis of the further continuation of the zone (in the basement of the Great Hungarian Plain and the Apuseni Mts.) the age of the thrusting was given as Late Cretaceous (Turonian, "pre-Gosau phase"; Császár 2002). The present-day form of the range and the locally very steep dipping of the beds were interpreted as positive flower structures generated by rather young (Quaternary) strike-slip movements (Bergerat and Csontos 1988; Csontos et al. 2002).

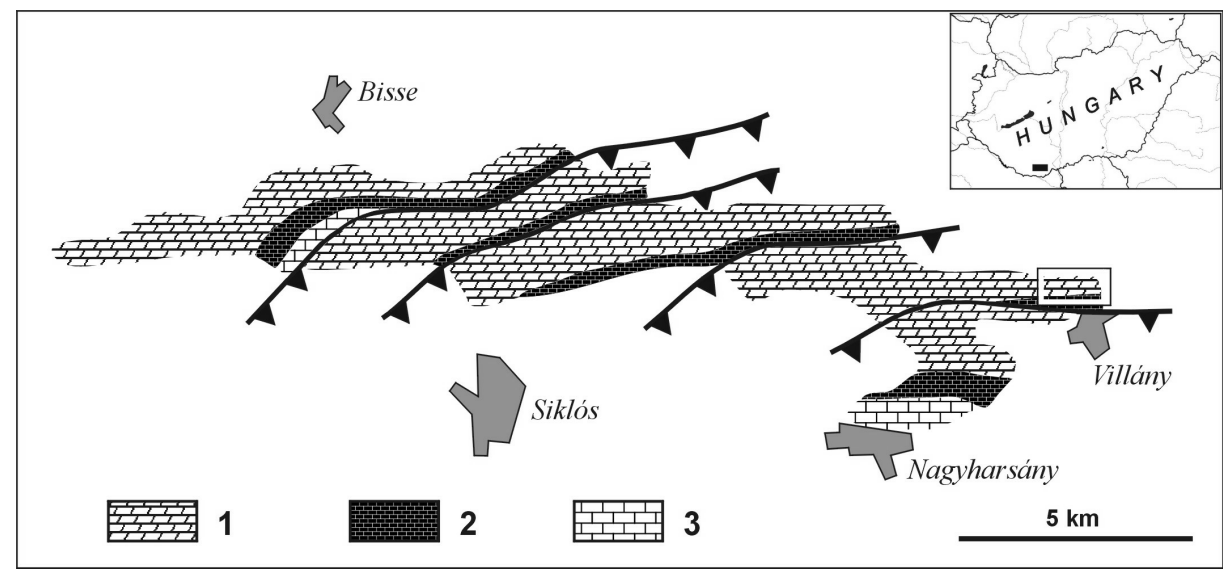

Fig. 1

Geologic sketch map of the Villány Hills. 1. Middle Triassic dolomite and limestone, 2. Middle and Upper Jurassic limestone, 3 . Cretaceous limestone. Barbed lines indicate thrust faults (modified after Fülöp 1966)

The Mesozoic stratigraphy of the Villány Hills is summarized in Fig. 2. In the following short description, based mainly on Bleahu et al. (1994), Császár (2002), Csontos and Vörös (2004), Haas and Péró (2004), and Vörös and Csontos (2006a), only certain specific characters of the formations or differences from the general features of the Villány-Bihor Zone will be stressed.

Fig. $2 \rightarrow$

Triassic to Lower Cretaceous sedimentary formations of the Villány Hills with approximate thickness data. The shadowed box shows the formations appearing at the Templom-hegy, Villany (modified from Vörös 2010) 


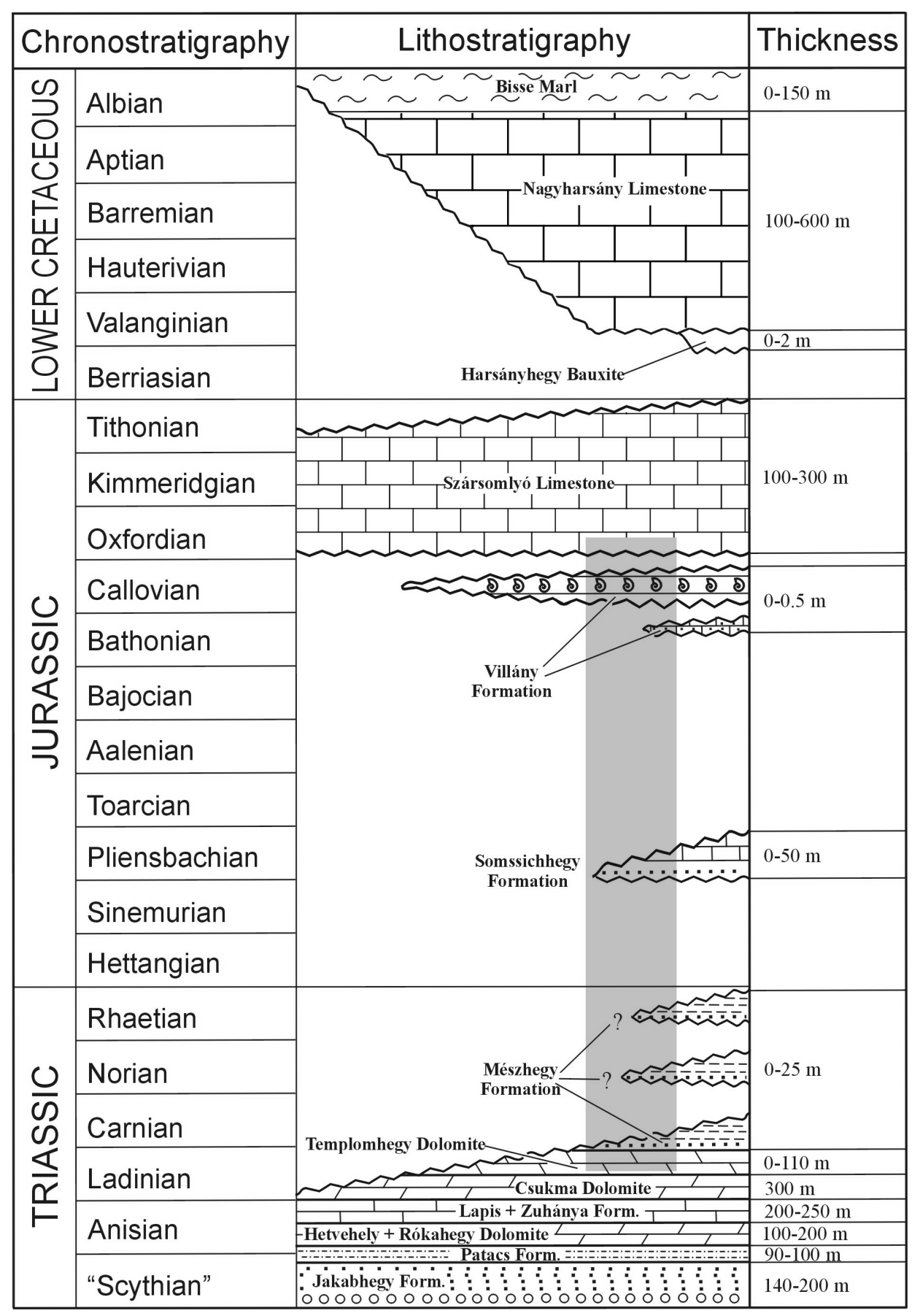


The Lower Triassic formations are known only in boreholes around the Villány Hills. The Middle Triassic formations, i.e. the trinity of the Rókahegy Dolomite, the Zuhánya Limestone and the Csukma Dolomite, with their more than $800 \mathrm{~m}$ of thickness, play the principal role in the geomorphology of the mountain range. The Templomhegy Dolomite is a specific formation of the Villány Hills because its thinly-bedded uppermost part is interlayered with thicker clay seams and shows apparent transition to the overlying Mészhegy Formation. This latter, "Keuperlike" sedimentary sequence is rather thin (less than $25 \mathrm{~m}$ ) and is preserved only as erosional remnants in pre-Jurassic tectonic depressions.

The Jurassic sedimentation begins with a transgressive series of Pliensbachian age. The basal, conglomeratic beds rest unconformably on the eroded top of the Mészhegy Formation; thereafter, with a decreasing amount of terrigenous clastics, pure limestone develops; the sequence is terminated by an erosional top surface. This Pliensbachian Somssichhegy Formation is also restricted to local tectonic depressions. The next, short sedimentary episode took place in the Late Bathonian, when a thin bed of sandy, marine limestone was deposited. It is also preserved in local lenses; in fact it is known only at the Templom-hegy (Villány). The first widespread Jurassic formation is the well-known Callovian stromatolitic, ammonitic bank. This deeper marine limestone, called Villány Formation, is uniformly thin (less than half a meter) and bounded by unconformities from below and above. From the Oxfordian, the previous episodic and condensed sedimentation switched to continuous and thick accumulation of pure limestone (Szársomlyó Limestone; $300 \mathrm{~m}$ ). The basal, micritic beds, which were called "pelagic oolite" by Jenkyns (1972) (in fact peloidal micrite) changes to increasingly shallow marine limestone up to the Tithonian.

The subaerial character of the next regional unconformity, in the earliest Cretaceous, is proved by bauxite, overlain by Urgon-type limestone of Valanginian to Albian age. This Nagyharsány Formation may exceed $400 \mathrm{~m}$ in thickness. Younger Cretaceous (Albian to Cenomanian) formations (Bisse Marl, Bóly Formation) occur only in the form of erosional fragments or in boreholes. The Late Cretaceous, Gosau-type sedimentary and volcanic rocks, very widespread and voluminous in the central and eastern part of the Villány-Bihor Zone, are not known in or around the Villány Hills

The Mesozoic succession of the Villány Hills may exceed the $2000 \mathrm{~m}$ of total thickness. Within this the Upper Triassic to Lower Jurassic sequences, the targets of the present study, seem to play a subordinate role because they are thin (well below $100 \mathrm{~m}$ ) and are arranged into a few, episodic sedimentary cycles. However, they provide an exceptional record of geologic events spanning a nearly 70 million-year interval between the Ladinian and Bathonian ages. These Upper Triassic to Lower Jurassic sequences are best (and almost exclusively) known from the Templom-hegy at Villány and in the following the paper will focus on this locality. 


\section{Previous research and short description of the outcrops of the Templom-hegy at Villány}

The Mesozoic formations of the Villány Hills, and especially those exposed on the Templom-hegy (Templom Hill) at Villány, have been among the most classical subjects of Hungarian geology. Moreover, the last-named locality, mostly by its extremely rich Jurassic ammonoid fauna, attracted the attention of the international scientific community.

Hoffmann (1876) was the first to give a concise and almost perfect description of the local geology; he rightly recognized the Middle Triassic, Middle Jurassic and Upper Jurassic formations, but erroneously emphasized the absence of the "Lias". Pálfy (1901) drew the first geologic cross-section of the Templom-hegy; this was improved by Till $(1906,1907)$, who provided a comprehensive stratigraphic information and published a monograph on the very rich Callovian ammonoid fauna (Till 1910-1911). This fauna was the subject of a next, even larger and world-famous monograph by Lóczy $(1915)$ who summarized the geologic knowledge of the area. Lóczy $(1912,1915,1945)$ recognized a curious, loose, clayey-sandy formation between the Middle Triassic and Jurassic carbonates what he regarded as Miocene in age. A significant advance was made by Szabó in 1957, whose university thesis was never published but the results of which were integrated into a textbook by Vadász (1960). Szabó constructed a perfect geologic cross-section through the Templom-hegy and revealed that the curious, loose complex is a regularly deposited member of the Mesozoic sequence. Ager and Callomon (1971) pointed out that the thick, basal formation of the Jurassic sequence (believed to be Bathonian for a century) is of Pliensbachian age. The present author (Vörös 1972) revised the Mesozoic stratigraphy of the Templomhegy and provided sedimentological data from the Pliensbachian strata and also from the above-mentioned "curious loose complex". The latter was regarded as a result of a short episode of sedimentation between the Middle Triassic and the Early Jurassic. This complex was newly exposed in 1979 and was described by Rálisch-Felgenhauer (1985) as the Mészhegy Sandstone Formation. The Late Triassic to Early Jurassic formations of the Templom-hegy were repeatedly portrayed in field guides (Vörös 1990; Vörös and Kordos 2007) and text-books (Haas 2001, 2004; Császár 2005) but without significant advance in geologic interpretation.

The Templom-hegy abounds in outcrops (quarries, road cut, tunnel, boreholes) which, four decades ago when the author started his studies on the area, were mostly in good condition, but nowadays many of them are destroyed or covered. The location of the outcrops relevant to the present study is shown in Fig. 3, with numbers corresponding to the paragraphs as follows.

1. The quarry at the railway station exposes the Ladinian Templomhegy Dolomite.

2. The abandoned road-cut at the Templom-hegy was exposed in historical times, then again in 1957 and 1979; now it is badly covered. It showed the upper- 


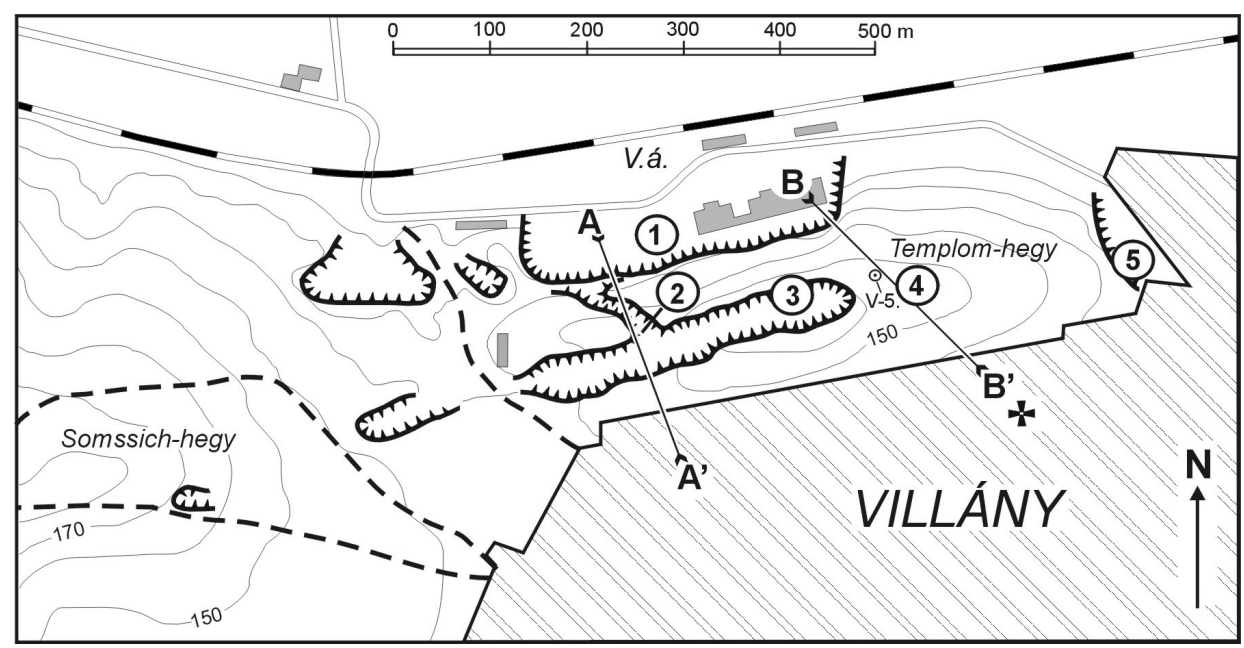

Fig. 3

The major surface and subsurface outcrops of the Templom-hegy and its surroundings at Villány, showing the lines of the geologic cross-sections "A" and "B". The numbering corresponds to the respective paragraphs in the text. The double-dashed line marks the approximate route of the "winetunnel". V. á.: railway station (modified from Vörös 2010)

most part of the Templomhegy Dolomite, the whole Mészhegy Formation and the Somssichhegy Formation.

3. The big quarry at the Templom-hegy is the principal outcrop of the area; at point No. 3 it exposes the top of the Upper Triassic Mészhegy Formation and the Jurassic Somssichhegy, Villány and Szársomlyó Formations.

4. The boreholes Villány-1, 2, 3, 4 and 5, drilled in 1967, penetrated different parts of the Mesozoic sequence at the Templom-hegy; from these wells, the one providing core V-5 was the most complete. The"wine-tunnel", constructed in 1968, crossed the entire Mesozoic succession of the Templom-hegy and exposed the Mészhegy and Somssichhegy Formations in reduced thickness. The "winecellar cave", discovered during the construction of the tunnel, was developed in steeply dipping $\left(180 / 60^{\circ}\right)$ Templomhegy Dolomite.

5 . The eastern quarry at the Templom-hegy exposes a reduced section, where the Mészhegy and Somssichhegy Formations are missing and the Middle Jurassic Villány Formation rests directly upon the Ladinian Templomhegy Dolomite.

\section{The outlines of the geology and Mesozoic stratigraphy of the Templom-hegy}

On the basis of the outcrops introduced above, the basic features of the geology of the Templom-hegy at Villány are demonstrated by two, approximately dip-directed cross-sections (Fig. 4). They clearly show the significant divergence between the dips and strikes of the two principal carbonate formations, the 

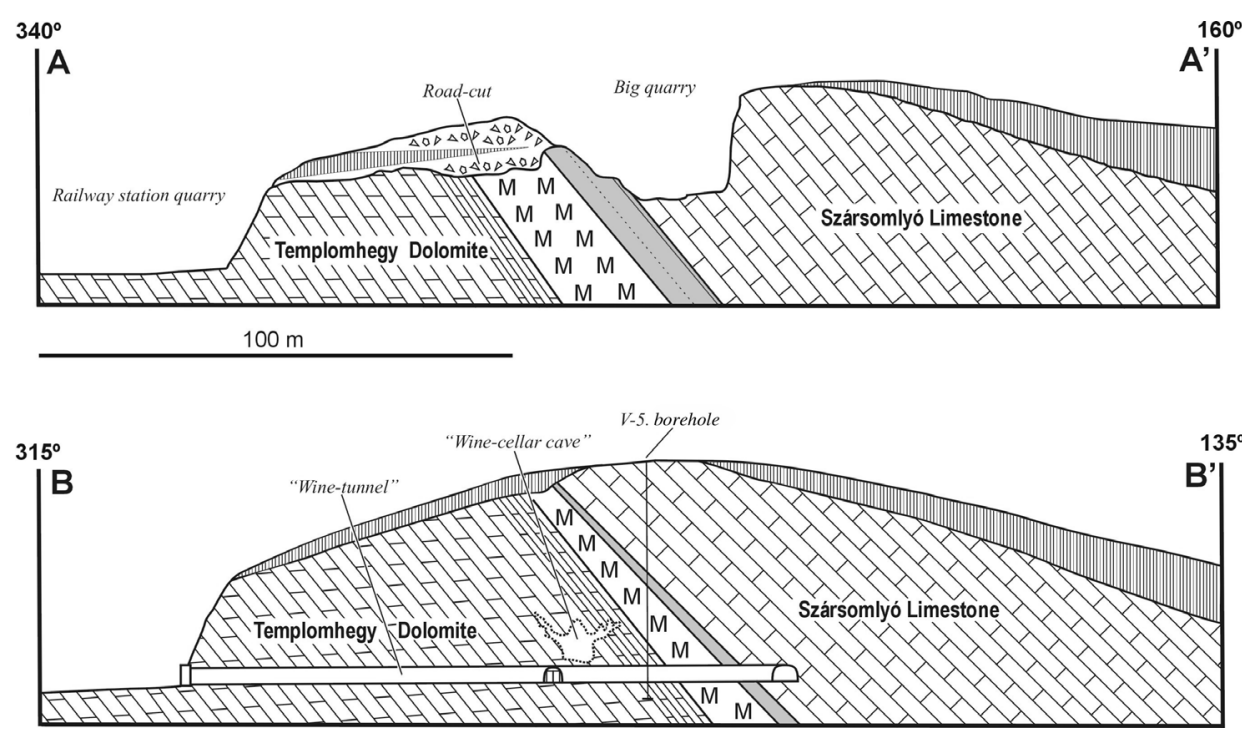

Fig. 4

Geologic cross-sections across the Templom-hegy at Villány, along the lines of the abandoned roadcut ("A") and the "boralagút" ("wine-tunnel") ("B"). M: Mészhegy Formation; dark shaded: Somssichhegy and Villány Formations. Further legend in Fig. 5 (modified from Vörös 2010)

Templomhegy Dolomite and the Szársomlyó Limestone. The dip data of the latter show a very narrow scatter; the average of ten measurements is $161 / 52^{\circ}$ (and this is applicable for the Villány Formation as well). On the other hand, the data measured in the Templomhegy Dolomite show wide variation $\left(163 / 61^{\circ}-173 / 50^{\circ}\right)$, with an average of $167 / 56^{\circ}$. Thus, the average dip of the Templomhegy Dolomite is consistently steeper. Furthermore, the thickness of the intervening Mészhegy and Somssichhegy Formations is noticeably greater in the western (A-A') section proving that also the strikes of the two principal formations deviate considerably.

The Mesozoic formations of the Templom-hegy are shortly described below (for more details see Vörös 2010 in press).

1. Templomhegy Dolomite Formation. This is the uppermost member of the Middle Triassic carbonate ramp complex of the Villány Hills. Comprehensive descriptions of this Ladinian, well-bedded, marly dolomite were given by Nagy and Nagy (1976) and Rálisch-Felgenhauer (1987).

2. Mészhegy Formation. This curious, loose, sandy-clayey formation was poorly exposed and inadequately known and, for a long time, it was regarded as Miocene in age. The best outcrop of the Mészhegy Formation, in an abandoned road-cut between the two main quarries of the Templom-hegy was excavated and perfectly cleaned up in 1979; its preliminary description was given by RálischFelgenhauer (1985). The section was also measured by the present author; a detailed photographic documentation is published elsewhere (Vörös 2010, in 
press). The description is summarized below and the stratigraphic column is shown in Fig. 5.

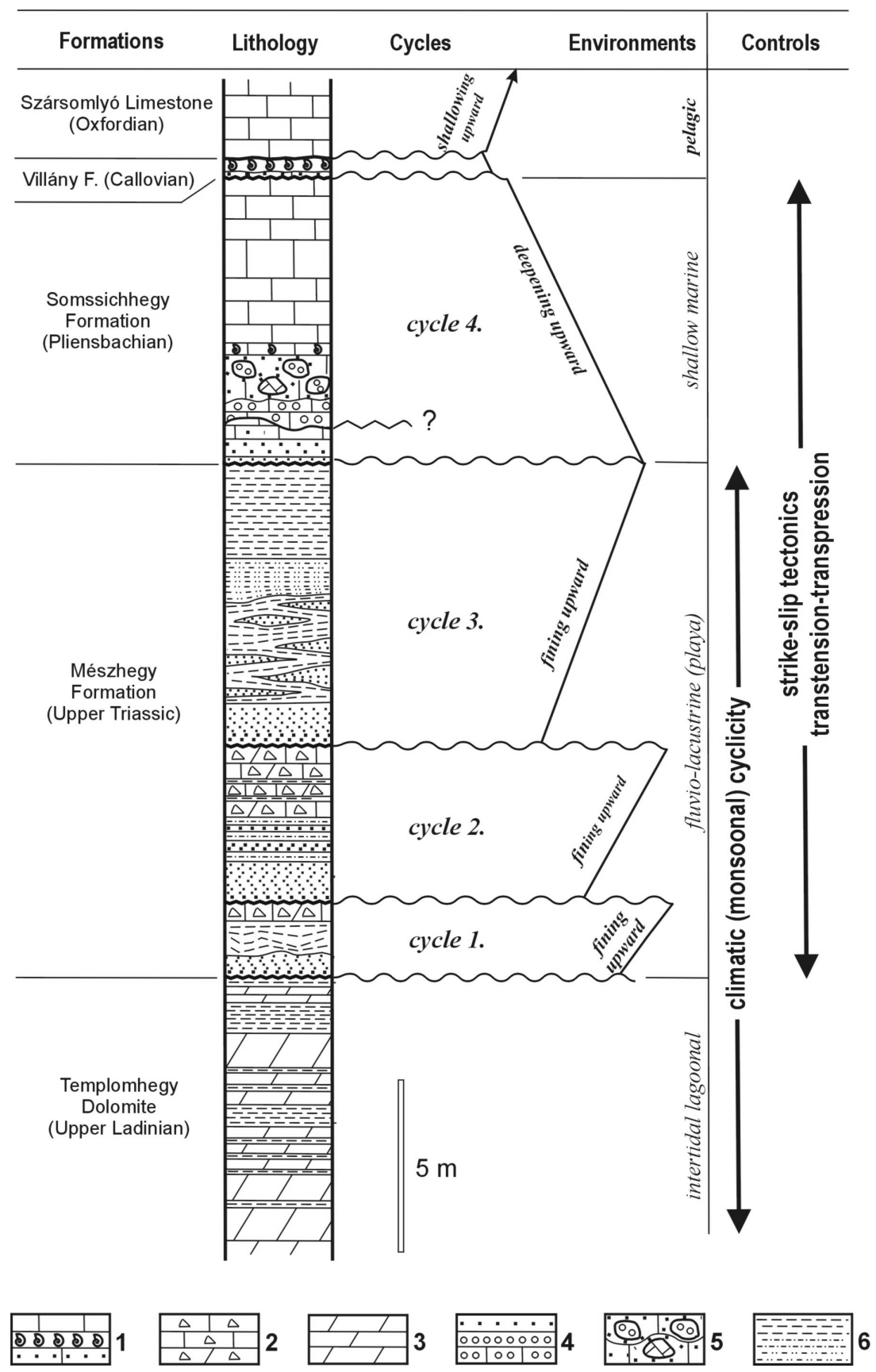


In its uppermost part, the thin beds of the Templomhegy Dolomite alternate with brownish clay layers. A thicker dolomite bed closes this formation, which is sharply overlain by the lowermost sandstone layer of the Mészhegy Formation. It is followed by variegated clay passing into cellular dolomitic limestone (calcrete, dolocrete). With a sharp contact, coarse sandstone follows. The thick sandstone shows a fining upward trend and passes into siltstone, then into cellular dolomitic limestone alternating with green clay. This is topped by a ferruginous crust and sharply overlain by grey sandstone. This fine-grained sandstone passes into siltstone and variegated clay, containing large, lenticular bodies of fine-grained sandstone. The uppermost part of the Mészhegy Formation is dominated by greenish-gray clay that is sharply overlain by the sandstone and conglomerate of the Lower Jurassic Somssichhegy Formation.

The age of this formation can probably be restricted to the Late Triassic; the three fining upward cycles probably represent three separate sedimentary episodes.

3. Somssichhegy Formation. It starts with yellowish, medium-grained quartz sandstone with carbonate matrix, resting with slight angular unconformity upon the Mészhegy Formation, and testifies to marine transgression. Within one meter, the sandstone passes into almost pure limestone. This limestone bed is of variable thickness and its upper boundary is sharp. An $80 \mathrm{~cm}$-thick conglomerate follows with increasing amount of quartzite and dolomite pebbles $(0.5$ to $2 \mathrm{~cm}$ in diameter) in a limestone matrix. The dolomite pebbles may have been derived from the deeper underlying Templomhegy Dolomite but the provenance of the dominant quartzite grains is uncertain: the underlying Mészhegy Formation does not contain detritus of such large grain-size. A remote source area consisting of Permian/Lower Triassic coarse clastic sediments (e.g. Jakabhegy Formation), or a crystalline basement may be supposed.

In the next unit, large pebbles or boulders of the conglomerate are embedded into a yellowish-grey clayey-sandy-pebbly limestone matrix; a little higher up large limestone pebbles also appear. This one meter-thick "boulder bed" was formed by redeposition of the directly underlying conglomerate and limestone layers reworked from a neighboring area.

With an abrupt decrease of the amount and grain-size of the siliciclastics, a 20-30 cm-thick yellowish-gray ammonitic-belemnitic-brachiopodal limestone develops; it contains many petrified driftwood pieces as well. The rich ammonoid fauna indicates the early Pliensbachian (Géczy 1998), and the basal members of this few meter-thick transgressive series are thought to be of the same age. The higher part of the $6 \mathrm{~m}$-thick limestone sequence becomes bluishgrey, thick-bedded or massive; ammonoids disappear but brachiopods, belemnites and bivalves occur sporadically.

$\leftarrow$ Fig. 5

Composite stratigraphic column of the Mesozoic (topmost Ladinian to basal Oxfordian) series exposed on the Templom-hegy at Villány, showing the sedimentary cycles, their environmental interpretation and controls of cyclicity (modified from Vörös 2010) 
4. Villány Formation. Following a long hiatus this formation begins with a less than $10 \mathrm{~cm}$-thick, yellow, Upper Bathonian sandy limestone bed (Altáró Bed). It pinches out within a short distance $(2-3 \mathrm{~m})$ and only some remnants, preserved in the surface irregularities of the underlying Pliensbachian limestone, or reworked pebbles in the overlying unit, are seen in other outcrops (Vörös 1972, 1990; Géczy and Galácz 1998).

The next, Templomhegy Member (the classical Callovian ammonitic bed) starts with a locally developed, $8-10 \mathrm{~cm}$-thick iron oolitic limestone horizon of early Callovian age. The dominant limonitic ooids have quartz or dolomite grains in their nuclei; large $(2-5 \mathrm{~cm})$ pebbles of the Bathonian sandy limestone with limonite crusts (oncoids) are also frequent (Vörös 1972; Géczy and Galácz 1998). The higher part of the ammonitic bed is very widespread and rather constant in thickness $(30-40 \mathrm{~cm})$ and is characteristically tripartite: the lower and upper levels consist of large $(5-10 \mathrm{~cm})$ stromatolitic oncoids grown around ammonite shells or belemnite rostra and embedded in pure limestone matrix; the middle level is a $5 \mathrm{~cm}$-thick, more or less continuous stromatolite mat with LLH structure, showing polygonal channeled surface (Radwanski and Szulczewski 1965, 1966). The micrite matrix and the predominance of nektonic fossils (ammonites, belemnites Paleotrix [=Bositra]) suggest a pelagic and relatively deep-marine environment (Vörös 1990). Consequently, the stromatolites are considered to be of deep-water origin, produced by some non-light-dependent group of microorganisms. As a result of heterogeneous condensation, the extremely rich ammonoid fauna contains elements of several successive middle and upper Callovian faunal horizons (Géczy 1982, 1984).

5. Szársomlyó Formation. It is widespread in the Villány Hills, attains $300 \mathrm{~m}$ of thickness and comprises the Oxfordian, Kimmeridgian and Tithonian Stages. It is best exposed at the Harsány-hegy (Szársomlyó) at the village Nagyharsány, where Kaszap $(1962,1963)$ performed a detailed microfacies study and pointed out a shallowing upward trend.

At the Templom-hegy, the lowermost part of the Szársomlyó Formation is exposed in the southern wall of the big quarry, in a thickness of at least $25 \mathrm{~m}$. It rests paraconformably upon the Callovian Villány Formation. The megafauna are extremely scarce; the microfauna of the basal beds are dominated by protoglobigerinids. A little higher in the sequence, peloids and microoncoids become dominant ("pelagic oolite"; Jenkyns 1972).

\section{The early Mesozoic cycles}

A composite stratigraphic column of the Mesozoic (Ladinian to Oxfordian) series exposed on the Templom-hegy at Villány is shown in Fig. 5; the recognized sedimentary half-cycles and their environmental interpretation are also displayed. 
In the Mészhegy Formation, three clearly separated sedimentary cycles can be recognized. They are of fining-upward character as a rule. All three rest on unconformity surfaces and start with coarser sandstone passing to finer clastics. In Parasequence 1 , of $2 \mathrm{~m}$ thickness, the sandstone is followed by variegated clay and, as an end-member, a clayey, cellular dolomitic limestone layer develops. In the nearly $5 \mathrm{~m}$-thick Cycle 2 the sandstone grades into siltstone; then this cycle is also terminated by cellular dolomitic limestone interlayered with variegated clay seams. Cycle 3 is the thickest (around $8 \mathrm{~m}$ ); the basal sandstone member is followed by clay with lenticular sandstone bodies, then, above siltstone layers, the closing member is thick, massive clay.

The three cycles of the Mészhegy Formation represent three phases of fluviolacustrine deposition in a local, Late Triassic basin. The basal sandstone layers can be interpreted as the initial, fluviatile members of the cycles; the siltstone and clayey layers can be regarded as lacustrine deposits, just as the cellular dolomitic end-members, which may be qualified as calcrete-dolocrete deposits formed by intermittent evaporation. In the absence of detailed sedimentological analysis, the latter interpretation is only circumstantial and based on analogies (e.g. with the playa cycles of the Germanic Keuper: Reinhardt and Ricken 2000; Vollmer et al. 2008) and the genetic order of the layers in question.

The cycles are, in fact, half-sequences, and are truncated: their upper boundary is sharp in each case; their uppermost part was obviously eroded.

The Somssichhegy Formation, at first glance, can be interpreted as a single, fining and deepening-upward cycle (Cycle 4; Fig. 5). The coarse-grained siliciclastic material, predominant in the lower levels, diminishes upward in amount and grain size, and a pure limestone sequence develops, with spiculitic cherty horizons in the highest part.

The marine depositional environment is proved by the rock-forming echinoderm, brachiopod and foraminifer skeletal material appearing in the lowermost one meter of the sequence; a little higher, the rich ammonoid fauna points to pelagic influence.

At closer inspection Cycle 4 can be subdivided into two sub-cycles. The lowermost sandstone beds of the formation, within one meter, pass into almost pure bioclastic limestone. The thickness of this limestone bed is variable; its upper boundary is sharp and irregular.

This lower sub-cycle is overlain by the bulk of the Somssichhegy Formation, i.e. the upper sub-cycle, which starts again with coarse siliciclastics. In its conglomeratic horizon, the limestone boulders originating from the underlying subcycle testify to erosion and reworking during deposition of the upper sub-cycle.

The age of the upper sub-cycle is definitely early Pliensbachian, as proved by the rich ammonoid fauna. The lower sub-cycle may be thought as of much older. The marine limestone bed did not provide any diagnostic fossils. The foraminifer fauna does not contain any forms pointing to Triassic age; they seem to be of Jurassic character (Á. Görög, pers. comm.). In the absence of any opposing 
evidence we may assign the lower sub-cycle to the Pliensbachian, but looking at the analogies in the paleogeographically neighboring areas (Mecsek, Bihar) where marine sedimentation begins in the Sinemurian, this older age cannot be definitely excluded.

The Villány Formation comprises at least two sedimentary cycles, which significantly differ from those discussed above. The deposition of these extremely condensed carbonates can be interpreted in terms of episodic sedimentation on a submarine plateau, and will be analyzed in detail in another paper.

The Szársomlyó Formation is represented by its lowermost portion in the Templom-hegy section. In the other parts of the Villány Hills this nearly $300 \mathrm{~m}$ thick formation shows clear features of a shallowing upward cycle. Further details are not evaluated in the present paper.

\section{The interpretation of the Late Triassic to Early Jurassic cyclicity}

\section{Mészhegy Formation}

The thickness and geometry of the cycles recognized in the Mészhegy Formation were determined by available accommodation space. In the present case the evaluation of the sedimentary features points to a broad fluviolacustrine environment; therefore it can be excluded that the occasional recurrence of the accommodation space was governed by global eustatic changes. Among further forces, the role of periodical changes of climate and local tectonic subsidence may be taken into account.

\section{Paleoclimatic control}

The abrupt appearance of the basal sandstones of the Mészhegy Formation above the Ladinian marly dolomite (Fig. 5) may be taken as a manifestation of the famous "Carnian pluvial event". Although the reality of this sudden increase of humidity in the Carnian of Europe was seriously doubted by Visscher et al. (1994), recent studies supported the idea of the "wet Carnian", evidenced in the Tethys ocean and on the surrounding lands of the Pangaea (Bourquin and Guillocheau 1996; Rigo et al. 2007; Porter and Gallois 2008; Kozur et al. 2009), also called the "Reingraben event" (Hornung et al. 2007).

The fining-upward trends within the three cycles of the Mészhegy Formation are thought to reflect climatic cyclicity from humid to arid conditions: sandstone (= fluviatile) $\rightarrow$ clay (= lacustrine) $\rightarrow$ calcrete-dolocrete (= evaporation in playa lake). Similar, fluvio-lacustrine cyclicity was recognized and described in similar, low-latitude regions (Newark Basin: Smoot 1991; Olsen and Kent 1996; Germanic Basin: Reinhardt and Ricken 2000; Vollmer et al. 2008) and was interpreted as orbitally forced monsoonal cyclicity. In these regions the lake-level changes of the 
large playa-lakes showed $20 \mathrm{kyr}$ (precession-related) and $100 \mathrm{kyr}, 413 \mathrm{kyr}$ and 2 Myr (eccentricity-related) cycles during the Late Triassic.

Obviously, the above model cannot be applied to the cycles of the Mészhegy Formation, where we have only three cycles instead of at least 12 (which would be predicted by the model, using the longest, i.e. $2 \mathrm{Myr}$, cycles and a $24 \mathrm{Myr}$ long Late Triassic). One of the reasons of this may be that the Mészhegy Formation does not represent the entire Late Triassic. We may further speculate whether the three cycles of the Mészhegy Formation were restricted to the Carnian, or each of them developed in the Carnian, Norian and Rhaetian, respectively, as was suggested by Bleahu et al. (1994). In any case paleoclimatic control in itself is not enough to explain their origin. The monsoonal cyclicity can be recognized in the Villány section (Fig. 5), perhaps even in the uppermost Ladinian part with the dolomite/clay alternations. Nevertheless, in the case of the cycles of the Mészhegy Formation, the episodic creation of the accommodation space requires a paleotectonic explanation.

\section{Paleotectonic control}

Field observations and data reveal that the thickness of the Mészhegy (and also the Somssichhegy) Formation shows considerable lateral changes: both wedge out to the east within the Templom-hegy. On the other hand the Middle and Upper Jurassic formations are of uniform thickness everywhere in this area. This may have a plausible paleotectonic reason: the basal, Middle Triassic dolomite suffered strong tectonic fragmentation before the Middle and Upper Jurassic formations uniformly sealed the area. It is also reasonable that the cycles recognized in the Mészhegy and Somssichhegy Formations were controlled by repeated local tectonic movements. This complex issue may be approached by a conceptual, strike-directed section through the Templom-hegy (Fig. 6).

As was shown above (Fig. 4) there is a distinct divergence between the average dips and strikes of the Templomhegy Dolomite and the Szársomlyó Limestone, which is $6^{\circ}$ at least and locally may reach $20^{\circ}$.

The vertically exaggerated section in Fig. 6 was constructed partly on the basis of the above observation, i.e. that the strikes of the Templomhegy Dolomite and the Szársomlyó Limestone significantly diverge. Using the minimum of $6^{\circ}$ divergence results in a $10 \mathrm{~m}$-deviation between the top of the Templomhegy Dolomite and the base of the Szársomlyó Limestone, within a distance of $100 \mathrm{~m}$. This kind of extrapolation of the dip data may be fallacious; therefore some, though regrettably few, real thickness data were also used for the construction of the section. Thus the thickness of the Somssichhegy Formation was measured as $8 \mathrm{~m}$ at the abandoned road-cut, $5 \mathrm{~m}$ at the eastern part of the big quarry, and 1.5 $\mathrm{m}$ in the line of the "wine-tunnel"; the Mészhegy Formation showed a thickness of $14 \mathrm{~m}$ at the abandoned road-cut and $7.5 \mathrm{~m}$ in the line of the "wine-tunnel"; and both formations are missing in the eastern quarry. 


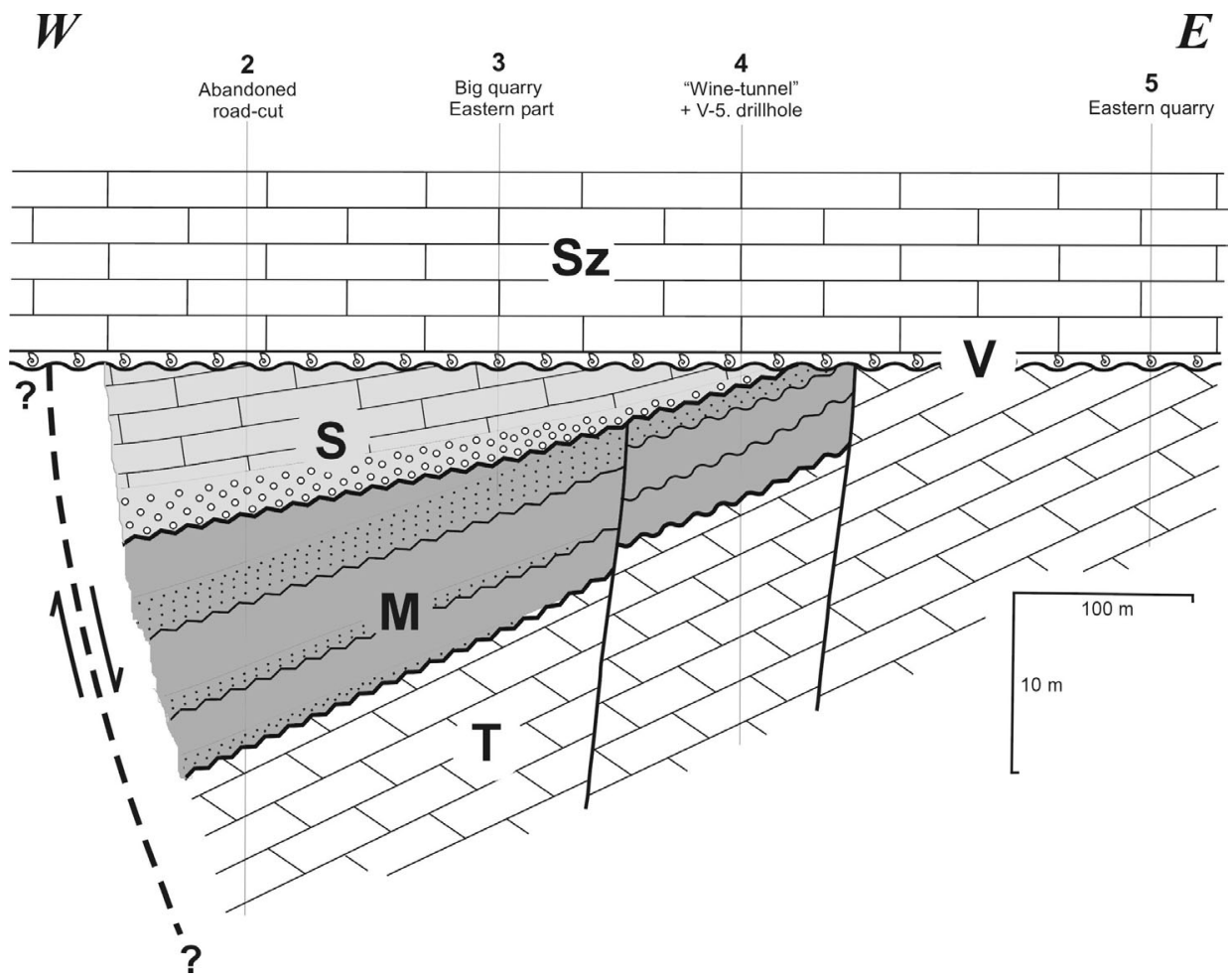

Fig. 6

E-W-trending conceptual cross section through the Templom-hegy at Villány (vertical exaggeration $\times 10$ ), showing the Late Triassic to Early Jurassic half-graben structure and the asymmetric accumulation of sediments. The numbering of the sites of thickness measurements corresponds to that in Fig. 3. Faults are inferred or speculative. M - Mészhegy Formation; T - Templomhegy Dolomite Formation; Sz - Szársomlyó Limestone Formation; V - Villány Formation. Further legend in Fig. 5 (modified from Vörös 2010)

On the constructed conceptual model (Fig. 6) the Villány + Szársomlyó Formations are portrayed in horizontal position, whereas the dismembered surface of the Templomhegy Dolomite delineates a westward dipping halfgraben, filled with the Mészhegy and Somssichhegy Formations. An essential element of the model is the listric normal fault in the west, governing the repeated rotational movements of the basement blocks of the half-graben structure. It is not localized; very probably it should lie outside of the present-day Templom-hegy. Its activity started in the latest Ladinian and persisted until the Middle Jurassic; the Callovian beds were not affected.

The spatial changes displayed within the three cycles of the Mészhegy Formation are rather speculative, because of the paucity of detailed observation. Nevertheless, it is probable that the cycles developed in the whole half-graben 
with thickness decreasing eastward. Remarkably, in the V-5 borehole clayey, cellular limestone prevails and sandstone layers are sporadic. This implies that the sandstone basal members of Cycles 1 and 2 wedge out eastward, and are substituted by clay and carbonates (calcrete, dolocrete).

In a paleogeographic interpretation, the deeper zones of the gently dipping asymmetrical basin received the fluviatile basal members (sandstones) of the cycles, while the wider, shallower parts of the basin was dominated by lacustrine sedimentation (clay, calcrete). After cyclical upfilling of the shallow basin, a longer period of subaerial exposure and non-deposition followed. Renewed movement along the listric normal fault and repeated block rotation resulted in the development of a new asymmetrical basin, which was filled up by the deposits of the next cycle, following the previous facies pattern. Thus, in the case of the cycles of the Mészhegy Formation, the available accommodation space was controlled by the repeated local tectonic movements. This sequence of events proceeded during the Late Triassic, in relatively short episodes, separated by longer time gaps.
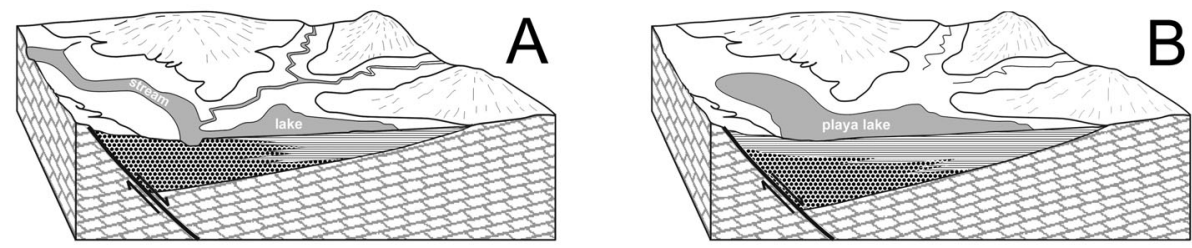

Fig. 7

Cartoon illustrating the development of the sedimentary cycles of the Mészhegy Formation. The accommodation space was created by rotational normal faulting. The first phase of each cycle is dominated by fluviatile sandstone deposition in the axial zone of the depression (A). The change of climate from humid to arid resulted in clay and calcrete-dolocrete deposition in a playa lake (B). This process recurred at least three times in the Late Triassic at Villány

Beside the fundamental tectonic control, the nature of the sediments implies fluctuation of the climate within each cycle. The fluviatile sandstones probably represent short, humid periods; the clays may have been deposited in a lacustrine environment, while the calcrete-dolocrete-like sediments may point to intermittent evaporation of the water (playa lake) (Fig. 7). Thus, the sedimentary cycles of the Mészhegy Formation are thought to reflect the interplay of tectonics and climate changes. The alternations of sedimentary environments were forced climatically, but the geometry and the episodic nature of the cycles were tectonically controlled.

\section{Somssichhegy Formation}

The eastward pinching out of the Somssichhegy Formation (Cycle 4) is well documented by data measured at several points; this phenomenon was also indicated by Vörös (1972, fig. 1). The lower, thin sub-cycle is known only in the 
type section; further to the east it was probably removed by the erosion of the next, upper cycle, because it appears in the form of boulders embedded in the basal beds of the upper cycle. The basal, coarse-grained detrital member of the upper, major cycle definitely thins out eastward (Fig. 6). The higher, limestone member of the Somssichhegy Formation is also thicker in the west, but in this case we must also consider the subsequent (pre-Middle Jurassic) erosion as a cause of this difference in thickness.

The two sub-cycles of the Somssichhegy Formation (Cycle 4) were deposited in pre-dominantly marine settings in the Early Jurassic. The initial, neritic, shallow sublittoral environment gradually changed into deep sublittoral, and it is highly probable that the distant areas of the Villány Hills were also flooded in the Pliensbachian. In spite of this transgressive phenomenon, even in the case of Cycle 4, the accommodation space is thought to have been created by local tectonic movements, and not by eustatic sea level rise. The relevant sea-level curves (e.g. Haq et al. 1987; Hallam 2001) show gradual sea-level rise in the first half of the Jurassic, yet, in Villány, the marine sedimentation was restricted to a Pliensbachian episode. Figure 6 shows that the tectonic regime, developed in the Late Triassic, also worked in the Early Jurassic: the half-graben structure controlled the pattern of sedimentation.

There is no sedimentary record in Villány from the Pliensbachian to the Bathonian. On the other hand, from the Bathonian-Callovian onwards, the structural and paleogeographic evolution of the area changed fundamentally. The normal faulting, previously governing the half-graben structures, ceased, and the area of the Villány Hills became a slowly subsiding uniform submarine plateau. This significant change in the tectonic evolution of the region can be interpreted in terms of the tectonic history of the wider paleogeographic surroundings.

\section{Megatectonic setting and early Mesozoic subsidence history of the Villány Hills}

The Villány Hills belong to the Villány-Bihor Zone of the Tisza (or Tisia) Terrane (Kovács et al. 2000; Haas 2001; Vörös and Csontos, 2006a). The Villany-Bihor Zone is the central unit, and in many respects the "backbone" of the Tisza Terrane. It differs markedly from the neighboring units by its Late Triassic to Early Cretaceous tectono-sedimentary evolution. The main features are incomplete and condensed sedimentation in the Late Triassic to Middle Jurassic interval and carbonate platforms in the Late Jurassic-Early Cretaceous times, in contrast to the essentially basinal facies of the Mecsek and Codru Zones to the north and south, respectively. From the end of the Middle Triassic onward the previously uniform Tisza Terrane began to disintegrate and the Villány-Bihor Zone behaved as a threshold flanked by subsiding basinal areas.

Another significant change at the Middle/Late Triassic connects the VillányBihor Zone to the Mecsek Zone. Both are characterized by the disruption of 
carbonate ramps into half-grabens and a switch of carbonate sedimentation to "Keuper-like" siliciclastic deposition in the asymmetric, fault-bounded basins. This fundamental tectono-sedimentary event was recognized here by Nagy $(1969,1971)$ who interpreted these phenomena as manifestations of the "Labian" tectonic phase. The dimensions of the half-grabens were extremely different in the Mecsek and Villány-Bihor Zones, but this tectonic style remained a common feature of the two zones until the mid-Jurassic.

This time interval, from the end of the Middle Triassic to the end of the Middle Jurassic, coincides with a period of nearly zero net crustal subsidence of the Villány area. The subsidence diagram constructed on the basis of thickness data of the Mesozoic formations of the Villány Hills was published by Vörös (2010, in press, fig. 27), and the respective curve is shown in Fig. 8, compared to representative subsidence curves of other selected European areas. The sources

Fig. 8

Subsidence curve of the Mesozoic formations of the Villány Hills, compared to the curves of the Southern Alps (eastern Lombardy), the Bakony (Hungary) and the Schwäbische Alb (Germany). Note the nearly horizontal portion of the Villány curve between the two arrows. Sources of stratigraphic data in Table 1. Age data from Gradstein et al. (2004). Ma million years; E. - Early; Mid. Middle; An. - Anisian; La. Ladinian; Car. - Carnian; Si. Sinemurian; Pl. - Pliensbachian; C - Callovian; O. - Oxfordian; Ti. - Tithonian; B. - Berriasian; Alb. - Albian, Schw. Schwäbische

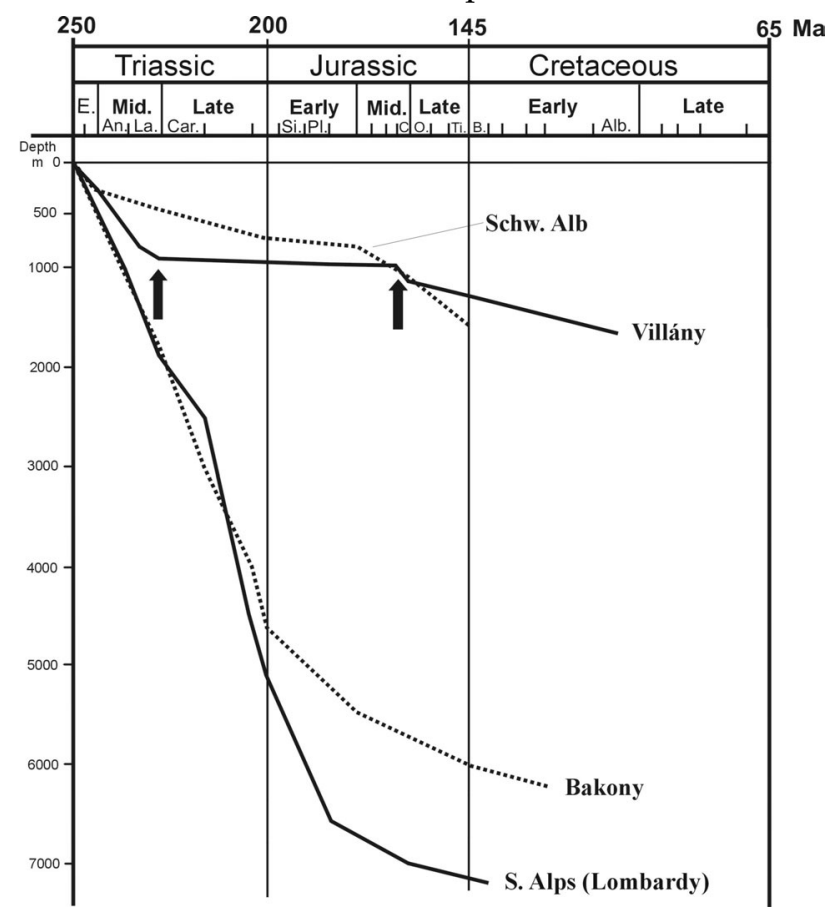

of data used for the construction of the subsidence curves are shown in Table 1 . In all cases, the curves correspond to the base level of the Triassic system, irrespective of the nature of its basement. The curves were constructed simply after the sedimentary thickness data and neither compaction nor eustatic sealevel changes were taken into account for correction. The compared sedimentary columns consist mostly of carbonate rocks which are presumed to have a similar degree of compaction; on the other hand, the global sea-level rose gradually from 
Table 1

Sources of stratigraphic data used for construction of the subsidence curves

\begin{tabular}{|c|c|c|c|}
\hline Area/section & Nature & Source & Details \\
\hline Schwäbische Alb (Germany) & constructed & Walter (1992) & p. $364+365$, fig. 125. \\
\hline $\begin{array}{l}\text { Briançonnais (France) } \\
\text { Vanoise occidentale }\end{array}$ & constructed & Gwinner (1971) & p. 65 , fig. 74 . \\
\hline $\begin{array}{l}\text { Briançonnais (Switzerland) } \\
\text { Préalpes médianes }\end{array}$ & constructed & Gwinner (1971) & p. 67 , fig. 78 . \\
\hline $\begin{array}{l}\text { Helvetic (Switzerland) } \\
\text { Vättis }\end{array}$ & original & Funk (1985) & p. 258 , fig. 7. \\
\hline $\begin{array}{l}\text { Helvetic (Switzerland) } \\
\text { Alvier }\end{array}$ & original & Funk (1985) & p. 266 , fig. 13 . \\
\hline $\begin{array}{l}\text { Southern Alps (Lombardy, Italy) } \\
\text { Val Camonica + Sebino }\end{array}$ & $\begin{array}{l}\text { constructed } \\
\text { (composite) }\end{array}$ & Galácz et al. (2006) & p. $176+596$, suppl. 48. \\
\hline $\begin{array}{l}\text { Bakony (Hungary) } \\
\text { Iszka Hill + Sümeg }\end{array}$ & $\begin{array}{l}\text { constructed } \\
\text { (composite) }\end{array}$ & Galácz (2006) & p. $55+573$, suppl. 23 \\
\hline $\begin{array}{l}\text { High Tatra (Poland) } \\
\text { Giewont }\end{array}$ & constructed & Vörös (2006) & p. $45+568$, suppl. 17 \\
\hline Villány (Hungary) & $\begin{array}{l}\text { original } \\
\text { (composite) }\end{array}$ & Vörös (2010, in press) & p. ??, fig. 27. \\
\hline $\begin{array}{l}\text { Mecsek S (Hungary) } \\
\text { Pécs }+ \text { Hosszúhetény }\end{array}$ & $\begin{array}{l}\text { constructed } \\
\text { (composite) }\end{array}$ & Vörös (2006) & p. $86+577$, suppl. 28 \\
\hline $\begin{array}{l}\text { Mecsek N (Hungary) } \\
\text { Nagymányok }+ \text { Ófalu }\end{array}$ & $\begin{array}{l}\text { constructed } \\
\text { (composite) }\end{array}$ & Vörös (2006) & p. $86+577$, suppl. 28 \\
\hline $\begin{array}{l}\text { Bihor (Romania) } \\
\text { Pădurea Craiului }\end{array}$ & constructed & Vörös (2006) & p. $90+578$, suppl. 29 \\
\hline
\end{tabular}

the Early Triassic to the mid-Cretaceous. Thus, the curves are biased in a similar degree; therefore they are believed to provide a good basis for comparison. The use of sedimentary thickness as the measure of crustal subsidence is justified in the cases where the respective part of the Mesozoic is represented by shallow marine sediments. In other cases (e.g. Bakony, Lombardy, Mecsek), where deepwater Jurassic is involved, further $500 \mathrm{~m}$ (for the Middle Jurassic) and $1000 \mathrm{~m}$ (for the Late Jurassic) are added arbitrarily to the subsidence curves.

The Villány subsidence diagram (Vörös 2010 fig. 27, and Fig. 8 herein) shows that in the first 20 million years of the Mesozoic, during the accumulation of Early Triassic siliciclastic sediments and Middle Triassic carbonate ramps/platforms, the area sank roughly $900 \mathrm{~m}$. Then, rather surprisingly, crustal subsidence was almost completely blocked for a long time: during the next nearly 70 million years net subsidence was around $50 \mathrm{~m}$. Beside the negligible sediment accumulation in the local basins, considerable erosion might have worked on the elevated parts of the tilted tectonic blocks, providing clastic input. The next 60 million year-long period of general subsidence (from the latest Middle Jurassic to the midCretaceous) can be divided into two parts: first the Szársomlyó Limestone Formation filled up the Late Jurassic basin and reached a pelagic platform stage; then, over the earliest Cretaceous karst bauxites, the shallow-water platform carbonates of the Nagyharsány Limestone Formation developed and kept pace 
with the subsidence until the middle Albian. By this time the total subsidence of the area attained $1700 \mathrm{~m}$.

Considering the above-mentioned long, Late Triassic-Middle Jurassic interval of "non-subsidence", the subsidence history of the Villány area is markedly different from that of other European regions (Fig. 8). The early Mesozoic subsidence curves of the peri-Tethyan outer shelves largely follow the usual trends of the post-rift subsidence of the passive continental margins: the Early and Middle Triassic intense subsidence continued in the Late Triassic and only slowly decreased until the Late Jurassic or Cretaceous collisions, and resulted in the accumulation of a 6-8 km thick sedimentary column (e.g.: Southern Alps: Winterer and Bosellini 1981; Transdanubian Mountains: Haas et al. 1995). Conversely, the Mesozoic subsidence curves of the inner continental areas of Europe (exemplified here by the sedimentary column of the Schwäbische Alb, Germany) show very slow but gradual subsidence until the Middle Jurassic, without any marked horizontal division, i.e. without the interruption and prolonged standstill of subsidence (Fig. 8).

On the other hand, the Villány subsidence curve shows good analogy with those of many intra-Alpine areas. Careful studies by Funk (1985), Wildi et al. (1989) and Wetzel et al. (2003) have demonstrated the presence of the Late Triassic to Early Jurassic "non-subsidence", i.e. a wide horizontal portion in many subsidence curves of the Swiss Jura and especially the Helvetic domain (e.g. Vättis, Fig. 9). The early Mesozoic sedimentary thickness data of certain sections of the Briançonnais Zone, the High Tatra and the Bihor Mts. portray a rather similar subsidence history (Fig. 9). All these curves, in spite of the locally very different total thickness values, clearly show a remarkable horizontal portion,

Fig. 9

Subsidence curve of the Mesozoic formations of the Villány Hills, compared to the curves of selected sections from the Helvetic and Briançonnais Zones (Western Alps, France, Switzerland), the High Tatra (Western Carpathians, Poland) and the Bihor Mts. (Apuseni Mts., Romania). The shadowed boxes designate the two main turning points in the subsidence histories of these areas; the supposed triggering events are also indicated. Sources of stratigraphic data in Table 1. Age data from Gradstein et al. (2004). Helv.: Helvetic; Bri.: Briançonnais; other abbreviations as in Fig. 8

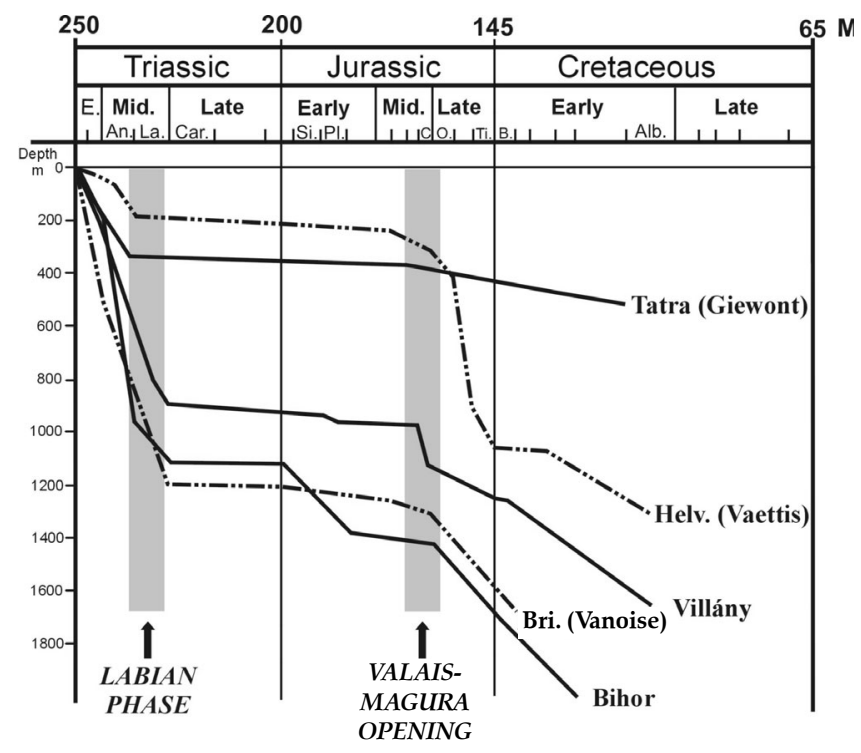


corresponding to the Late Triassic-Middle Jurassic interval of "non-subsidence". Some other domains of the Alps and West Carpathians (e.g. central Penninic and Czorsztyn) are reasonably thought to be included within this assemblage of units but their Mesozoic sedimentary record is regrettably scanty for the drawing of subsidence curves. In many relevant paleogeographic reconstructions for the Triassic, these areas were located at some distance from the Tethys, within the European shelf, mostly northward of the future Ligurian-Penninic-Váh oceanic belt (Michalík and Kováč 1982; Tollmann 1987; Ziegler 1988; Dercourt et al. 1990; Vörös 1993; Haas et al. 1995; Haas and Péró 2004; Csontos and Vörös 2004; Vörös and Csontos 2006b), which was less affected by the thermal subsidence of the passive Tethyan continental margins. This might be the cause of the restricted average thickness of the total Mesozoic sedimentary column, but does not explain the halt and the long-term delay of the subsidence. The total thickness is locally great in the "graben facies" (e.g. Mecsek) but even in these sections a midTriassic break can be recognized in the subsidence curves. It is important to underscore that the first phase of the subsidence history of this intra-Alpine belt region, i.e. the rapid subsidence until the mid-Triassic, approximately matched that of the outer continental margins (Southern Alps, Bakony) (Fig. 8).

The end-Middle Triassic tectonic event (Labian phase: Nagy 1969, 1971) is the link between the formation of half-grabens and the inversion and the change in the subsidence rate in the Mecsek and Villány-Bihor Zones, and in the abovementioned belt of the Alpine-Carpathian region. It seems that the major part of this belt, in contrast to the peri-Tethyan outer shelves, was dominated by compression (complemented with local extension) for nearly 70 million years. This partly elevated belt, with emerged ridges and local half-grabens may be called the Paleoalpine Range.

The compressive stress field might have been produced by the ongoing Cimmerian orogeny (Sengör et al. 1980; Michalík and Kováč 1982; Ziegler 1988; Jurewicz 2005), when, by the subduction of a Paleotethys arm, the Cimmerian continent collided with the Laurasian margin. According to the detailed analysis by Sengör (1984), however, the resulting fold-belt, strongly developed across Iran and Anatolia, did not reach beyond the Balkans or perhaps the Eastern Carpathians, and did not affect the westernly-lying Alpine-Carpathian areas. The onset of the fundamental tectonic changes in the Paleoalpine Range can surely be connected to the Labian phase of the Cimmerian orogeny in time, but since true shortening (thrust-folds, nappes) is not recorded, the steady compression lasting until the mid-Jurassic must have another cause.

It is more probable that the long-term compression along the Paleoalpine Range was produced by the stress field of a strong sinistral strike-slip zone, where, besides the prevailing transpression, transtensional basins might have been formed (Vörös and Csontos 2006b). In fact, everywhere in the well-studied parts of the Paleoalpine Range, one can find "graben facies" close to the "ridge facies", i.e. thick sediment accumulations close to the reduced and incomplete 
sequences. This is well demonstrated in the Helvetic and the Briançonnais Zones where, especially in the Jurassic, the grabens sank excessively (Fig. 10). The difference between the subsidence rates of the ridge and graben is even more

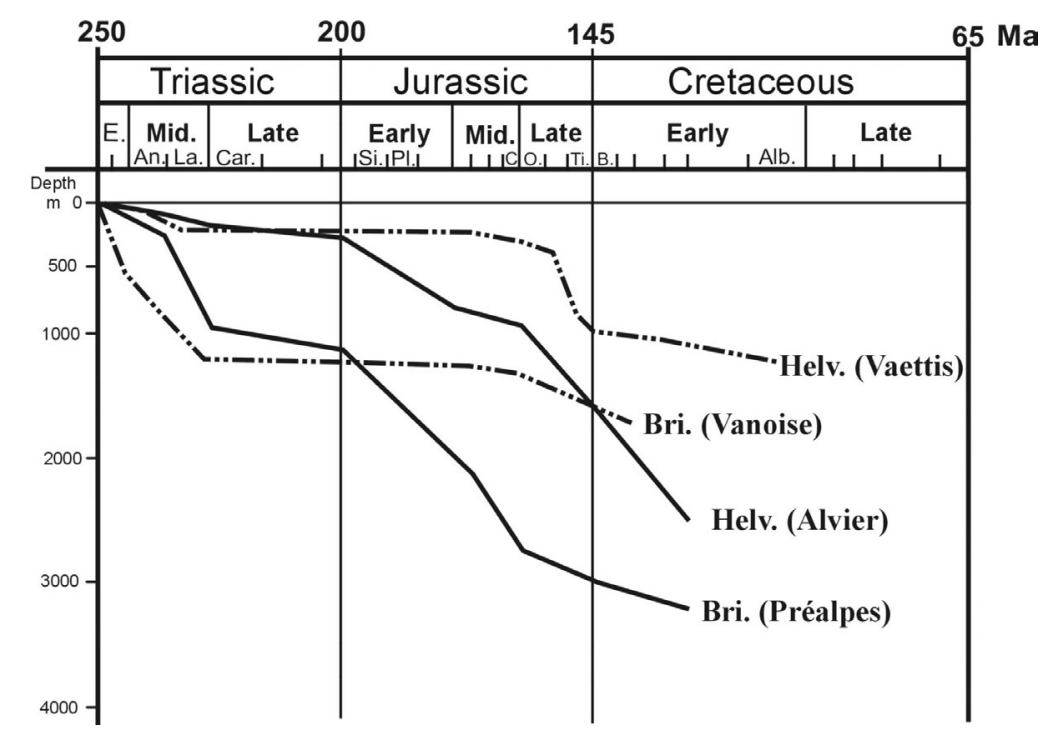

Fig. 10

Subsidence curves of selected ridge and graben successions of the Western Alps. Sources of stratigraphic data in Table 1. Age data from Gradstein et al. (2004). Abbreviations as in Fig. 8

spectacular within the Tisza unit, between the Villány and the Mecsek Zones (Fig. 11), though it must be noted that the Mecsek $S$ column (near Pécs) is exceptionally thick within the entire Mecsek Zone of the Tisza Unit. Looking at Figs 10 and 11, it is remarkable that a nearly horizontal Late Triassic segment, or at least a mid-Triassic break in the subsidence curves, can be recognized even in the cases of the "graben facies". The array of elevated, tilted blocks and adjacent half-grabens, as resulting from transpression and transtension, are characteristic features of strike-slip zones.

This wide and complex zone (Paleoalpine Range) was connected to global lithospheric plate boundaries. In the Late Triassic and Early Jurassic there was a large-scale sinistral strike slip zone along the future Central Atlantic (Swanson 1982) where rifting started in the Carnian (Piqué and Laville 1996; Le Roy and Piqué 2001). This major rift zone reached to the Alpine region through a Maghreb transform zone (Trümpy 1988; Ziegler 1988) and thus to the Paleoalpine Range as well. Here the transpressional stress field still persisted during the time of the initial opening of the Central Atlantic (Toarcian-Aalenian: Hallam 1975; Stampfli and Borel 2002). The Early Jurassic birth of the Ligurian-Penninic oceanic belt had little effect on the Paleoalpine Range; the transpression continued until the end 


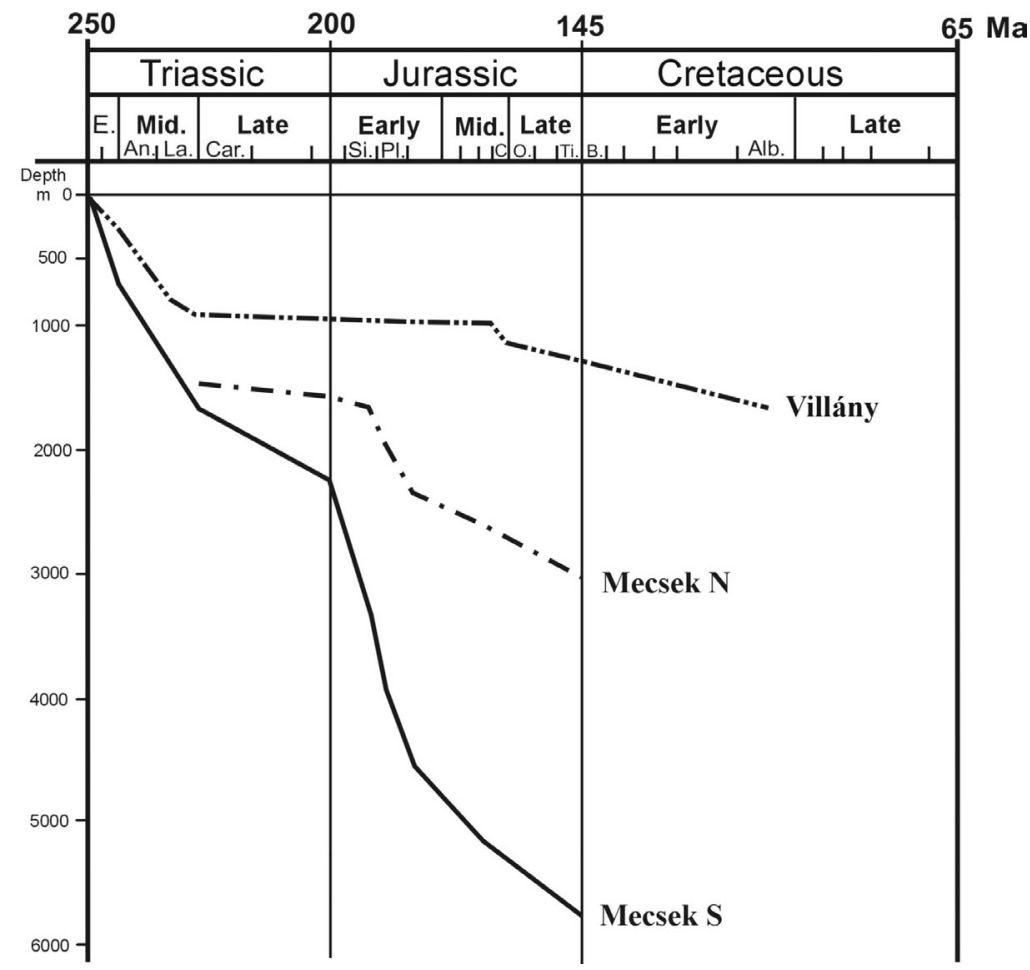

Fig. 11

Subsidence curves of ridge (Villány) and graben (Mecsek) successions of the Tisza Unit (Hungary). The Mecsek S section is of exceptionally great thickness. The Mecsek $\mathrm{N}$ section is nearer to mean thickness in the Mecsek Zone but its Lower to Middle Triassic part is unknown. Sources of stratigraphic data in Table 1. Age data from Gradstein et al. (2004). Abbreviations as in Fig. 8

of the Middle Jurassic, when the Valais-Magura oceanized belt of Baja Californiatype opened along the previous strike-slip zones. By this movement the compression ceased and the Paleoalpine Range was dissected: the Helvetic units remained on the European continental margin, while the Briançonnais, Central Penninic, Tatric and Tisza Units became partly (Trümpy 1988; Vörös 1993; Csontos and Vörös 2004; Haas and Péró 2004) or entirely independent from the European shelf as microcontinents (continental fragments) (Michalík and Kováč 1982; Jurewicz 2005; Vörös and Csontos 2006b). From this time onward the fragments of the Paleoalpine Range (Briançonnais, Central Penninic, Czorsztyn, High Tatric, Villány-Bihor) were surrounded by oceanic or transitional crust on both sides, and in the Late Jurassic, their subsidence rates approximated again the usual values of subsidence of the passive continental margins. However, they kept their relatively elevated, submarine ridge position, because the thinning process of their continental crust was interrupted and hindered for nearly 70 million years. 


\section{Conclusions}

1. Several sedimentary cycles were recognized in the early Mesozoic formations exposed on the Templom-hegy at Villány. From among them three fluvio-lacustrine, fining-upward cycles in the Late Triassic and one (or possibly two), marine, fining and deepening-upward in the Early Jurassic are demonstrated and evaluated in detail.

2. The Late Triassic and Early Jurassic cycles were deposited in a westwardtilted half-graben structure, where the repeated tectonic movements were primarily responsible for the episodic and cyclic nature of the sedimentation. The fining-upward trends within the three Late Triassic cycles are interpreted as reflecting climatic changes from humid to arid conditions.

3. The two Early Jurassic sub-cycles were deposited also in a half-graben, but in dominantly marine setting. The initial, neritic, shallow sublittoral environment gradually changed into deep sublittoral, and it is highly probable that the distant areas of the Villány Hills were also flooded in the Pliensbachian. For the Middle Jurassic the paleotectonic regime changed: the faulting ceased and the area started to sink uniformly.

4. The Mesozoic subsidence history of the Villány area has close analogies in the contemporaneous blocks of the European inner shelf domain (Helvetic, Briançonnais, (central Penninic, Czorsztyn), and High Tatric Ridges, Bihor Autochthon). Their common features are the intensive subsidence in the Early and Middle Triassic, followed by a long interruption of subsidence in the Late Triassic to Middle Jurassic, then a renewed, rapid subsidence in the Late Jurassic.

5. From the mid-Triassic "Labian phase", the above-mentioned intra-Alpine territories belonged to a transpression / transtension-dominated strike-slip zone for nearly 70 million years, until the Middle/Late Jurassic opening of the ValaisMagura oceanic belt, but even afterward they usually kept their relatively elevated, submarine ridge position.

\section{Acknowledgements}

Sincere thanks are given to Barnabás Géczy and András Galácz, who gave me indispensable help, both in the field work and in the improvement of my scientific approaches, at the beginning of my studies in Villány and thereafter. Special thanks are due to my colleagues Tamás Budai, Annette Götz, András Kaszap, Gyula Konrád, József Pálfy, István Szente and the late Elemér Nagy, Péter Szabó and János Oravecz, for valuable comments and advice. My views on the paleogeographic interpretation of the Villány Mesozoic have been greatly advanced by the numerous joint field trips and discussions with Krzysztof Birkenmajer, Sever Bordea, Tamás Budai, Géza Császár, László Csontos, András Galácz, Hanspeter Funk, János Haas, Ferenc Horváth, Miklós Kázmér, Gheorghe Mantea, Jozef Michalík, Jozef Pevný, Csaba Péró, Erzsébet Rálisch-Felgenhauer 
and Ákos Török. The useful reviewer's comments and corrections by János Haas and Géza Császár are deeply acknowledged.

\section{References}

Ager, D. V., J. H. Callomon 1971: On the Liassic age of the "Bathonian" of Villány (Baranya). Annales Universitatis Scientiarum Budapestinensis de Rolando Eötvös nominatae, Sectio Geologica, 14, pp. 5-16.

Bergerat, F, L. Csontos 1988: Brittle tectonics and paleo-stress field in the Mecsek-Villány mountains (Hungary): correlation with the opening mechanism of the Pannonian Basin. - Acta Geologica Hungarica, 31, pp. 81-100.

Bleahu, M., S. Bordea, S. Panin, M. Stefanescu, K. Sikić, J. Haas, S. Kovács, Cs. Péró, A. Bérczi-Makk, Gy. Konrád, E. Nagy, E. Rálisch-Felgenhauer, Á. Török 1994: Triassic facies types, evolution and paleogeographic relations of the Tisza Megaunit. - Acta Geologica Hungarica, 37/3-4, pp. $187-234$.

Bourquin, S., F. Guillocheau 1996: Keuper stratigraphic cycles in the Paris Basin and comparison with cycles in other Peritethyan basins (German Basin and Bresse-Jura Basin). - Sedimentary Geology, 105, pp. 159-182.

Császár, G. 2002: Urgon formations in Hungary. - Geologica Hungarica, Series Geologica, 25, pp. 1-209.

Császár, G. 2005: Magyarország és környezetének regionális földtana, I. Paleozoikum-paleogén [Regional geology of Hungary and its surroundings, I. Paleozoic-Paleogene]. - Eötvös Kiadó, Budapest, $328 \mathrm{p}$.

Csontos, L., L. Benkovics, F. Bergerat, J.-L. Mansy, G. Wórum 2002: Tertiary deformation history from seismic section study and fault analysis in a former European Tethyan margin (the Mecsek-Villány area, SW Hungary). - Tectonophysics, 357, pp. 81-102.

Csontos, L., A. Vörös 2004: Mesozoic plate tectonic reconstruction of the Carpathian region. Palaeogeography, Palaeoclimatology, Palaeoecology, 210, pp. 1-56.

Dercourt, J., L. E. Ricou, S. Adamia, G. Császár, H. Funk, J. Lefeld, M. Rakús, M. Sandulescu, A. Tollmann, P. Tchoumatchenko 1990: Northern Margin of Tethys. Paleogeographical Maps. Geologický Ústav Dionyza Štúra, Bratislava.

Funk, H. 1985: Mezozoische Subsidenzgeschichte im Helvetischen Schelf der Ostschweiz. - Eclogae geologicae Helvetiae, 78/2, pp. 249-272.

Fülöp, J. 1966: Les formations crétacées de la Montagne de Villány. - Geologica Hungarica, Series Geologica, 15, pp. 1-131.

Galácz, A. 2006: Mesozoic stratigraphy of the Transdanubian Central Range. - In: Horváth, F, A. Galácz (Eds): The Carpathian-Pannonian Region. A review of Mesozoic-Cenozoic stratigraphy and tectonics. - Geologica Pannonica Special Publication 1, pp. 55-61, Hantken Press, Budapest $624 \mathrm{p}$.

Galácz, A., A. Vörös, C. Doglioni, M. Kázmér 2006: Mesozoic stratigraphy of the Southern Alps. - In: Horváth, F, A. Galácz (Eds): The Carpathian-Pannonian Region. A review of Mesozoic-Cenozoic stratigraphy and tectonics. - Geologica Pannonica Special Publication 1, pp. 84-118, Hantken Press, Budapest, 624 p.

Géczy, B. 1982: A villányi jura ammoniteszek (Les Ammonites jurassiques de Villány). - Földtani Közlöny, 112, pp. 363-371. (In Hungarian with French abstract)

Géczy, B. 1984: The Jurassic ammonites of Villány. - Annales Universitatis Scientiarum Budapestinensis de Rolando Eötvös nominatae, Sectio Geologica, 24 (1982), pp. 189-198.

Géczy, B. 1998: Lower Pliensbachian ammonites of Villány (Hungary). - Hantkeniana, 2, pp. 5-47.

Géczy, B., A. Galácz 1998: Bathonian ammonites from the classic Middle Jurassic locality of Villány, South Hungary. - Revue de Paléobiologie, 17/2, pp. 479-511.

Gradstein, F, J. Ogg, A. Smith 2004: A geological time scale. - Cambridge University Press, 589 p. 
Gwinner, M. P. 1971: Geologie der Alpen. Stratigraphie, Paläogeographie, Tektonik. Schweitzerbart'sche, Stuttgart, $477 \mathrm{p}$.

Haas, J. (ed.) 2001: Geology of Hungary. - Eötvös University Press, Budapest, 317 p.

Haas J. (ed.) 2004: Magyarország geológiája, Triász (Geology of Hungary, Triassic). - Eötvös Kiadó, Budapest, $384 \mathrm{p}$.

Haas, J., S. Kovács, Á. Török 1995: Early Alpine shelf evolution in the Hungarian segments of the Tethys margin. - Acta Geologica Hungarica, 38/2, pp. 95-110.

Haas, J., Cs. Péró 2004: Mesozoic evolution of the Tisza Mega-unit. - International Journal of Earth Sciences, 93, pp. 297-313.

Hallam, A. 1975: Jurassic environments. - Cambridge University Press, London, New York, Melbourne, $269 \mathrm{p}$.

Hallam, A. 2001: A review of the broad pattern of Jurassic sea-level changes and their possible causes in the light of current knowledge. - Palaeogeography, Palaeoclimatology, Palaeoecology, 167/1-2, pp. 23-37.

Haq, B. U., J. Hardenbol, P. R. Vail 1987: Chronology of fluctuating sea levels since the Triassic (250 million years ago to present). - Science, 235, pp. 1156-1167.

Hoffmann, K. 1876: Mittheilungen der Geologen der k. ungar. geologischen Anstalt über ihre Aufnahmsarbeiten in den Jahren 1874 und 1875, b). - Verhandlungen der kaiserlichköniglichen geologischen Reichsanstalt (1876/1), pp. 22-24.

Hornung, T, L. Krystyn, R. Brandner 2007: A Tethys-wide mid-Carnian (Upper Triassic) carbonate productivity crisis: Evidence for the Alpine Reingraben Event from Spiti (Indian Himalaya)? Journal of Asian Earth Sciences, 30, pp. 285-302.

Jenkyns, H. C. 1972: Pelagic "oolites" from the Tethyan Jurassic. - Journal of Geology, 80, pp. 21-33. Jurewicz, E. 2005: Geodynamic evolution of the Tatra Mts. and the Pieniny Klippen Belt (Western Carpathians): problems and comments. - Acta Geologica Polonica, 55/3, pp. 295-338.

Kaszap, A. 1962: A Villányi-hegység malm rétegeinek mikrofácies-vizsgálata (Mikrofazies der Malmschichten im Villányer Gebirge). - Földtani Közlöny, 92/1, pp. 61-68.

Kaszap, A. 1963: Investigations on the microfacies of the Malm beds of the Villany Mountains. Annales Universitatis Scientiarum Budapestinensis de Rolando Eötvös nominatae, Sectio Geologica, 6, pp. 47-57.

Kovács, S., T. Szederkényi, J. Haas, Gy. Buda, G. Császár, A. Nagymarosy 2000: Tectonostratigraphic terranes in the pre-Neogene basement of the Hungarian part of the Pannonian area. - Acta Geologica Hungarica, 43/3, pp. 225-328.

Kozur, H., P. Moix, P. Ozsvárt 2009: New Spumellaria (Radiolaria) from the early Tuvalian Spongotortilispinus moixi Zone of Southeastern Turkey, with some remarks on the age of this fauna. - Jahrbuch der Geologischen Bundesanstalt, 149/1, pp. 25-59.

Le Roy, P., A. Piqué 2001: Triassic-Liassic Western Moroccan synrift basins in relation to Central Atlantic opening. - Marine Geology, 172/3-4, pp. 359-381.

Lóczy, L., ifj. 1912: A Villányi és Báni hegység geológiai viszonyai. Die geologische Verhältnisse der Villányer und Báner Gebirge. - Földtani Közlöny, 42, pp. 672-695, 781-807.

Lóczy, L., ifj. 1915: Monographie der Villányer Callovien-Ammoniten. - Geologica Hungarica, 1/3-4, pp. 255-502.

Lóczy, L. 1945: Igazgatói jelentés a m. Kir. Földtani Intézet 1943. évi múködéséről. Direktionsbericht über die Tätigkeit des Kön. Ung. Geologischen Anstalt im Jahre 1943. - A Magyar Állami Földtani Intézet Évi Jelentése 1943-ról, pp. 1-45, 47-82.

Michalík, J., M. Kováč 1982: On some problems of palinspastic reconstructions and Ceno-Mesozoic paleogeographical development of the Western Carpathians. - Geologický Zborník, Geologica Carpathica, 33/4, pp. 481-507.

Nagy E. 1969: A Mecsek hegység alsóliász kôszénösszlete. Földtan (Unterlias-Kohlenserie des Mecsek-Gebirges. Geologie). - A Magyar Állami Földtani Intézet Évkönyve, 51/2, pp. 1-970. 
Nagy E. 1971: A lábai fázis jelentősége a Dunántúl szerkezetfejlődése szempontjából (Significance of the Laban phase in view of the structural development of Transdanubia). - A Magyar Állami Földtani Intézet Évi Jelentése 1969-ról, pp. 583-586.

Nagy, E., I. Nagy 1976: Triasbildungen des Villányer Gebirges. - Geologica Hungarica, Series Geologica, 17, pp. 113-227.

Olsen, P. E., D. V. Kent 1996: Milankovitch climate forcing in the tropics of Pangaea during the Late Triassic. - Palaeogeography, Palaeoclimatology, Palaeoecology, 122, pp. 1-26.

Pálfy, M. 1901: Geológiai jegyzetek néhány dunamenti kőbányáról (Geological notes on some quarries along the Danube). - Földtani Közlöny, 31, pp. 150-155.

Piqué, A., E. Laville 1996: The Central Atlantic rifting: reactivation of Palaeozoic structures? Journal of Geodynamics, 21/3, pp. 235-255.

Porter, R. J., R. W. Gallois 2008: Identifying fluvio-lacustrine intervals in thick playa-lake successions: An integrated sedimentology and ichnology of arenaceous members in the mid-late Triassic Mercia Mudstone Group of south-west England, UK. - Palaeogeography, Palaeoclimatology, Palaeoecology, 270, pp. 381-398.

Radwanski, A., A. Szulczewski 1965: Stromatolitok a Villányi-hegység jura rétegeiben (Preliminary note on the Jurassic Stromatolites of the Villány Mountains). - Földtani Közlöny, 95/4, pp. $418-422$.

Radwanski, A., A. Szulczewski 1966: Jurassic stromatolites of the Villány Mountains (Southern Hungary). - Annales Universitatis Scientiarum Budapestinensis de Rolando Eötvös nominatae, Sectio Geologica, 9 (1965), pp. 87-107.

Rálisch-Felgenhauer E. 1985: Villányi-hegység, Villány, Templom-hegyi siklóbevágás (Villány Mountains, Villány, Sikló-cut of Templomhegy). - In: Magyarország geológiai alapszelvényei (Geological key-sections of Hungary). MÁFI, Budapest, 5 p.

Rálisch-Felgenhauer E. 1987: Villányi-hegység, Villány, Templom-hegyi alsó kőfejtő (Lower quarry of Templom-hegy, Villány, Villány Mountains). - In: Magyarország geológiai alapszelvényei (Geological key-sections of Hungary). MÁFI, Budapest, 5 p.

Reinhardt, L., W. Ricken 2000: The stratigraphic and geochemical record of Playa Cycles: monitoring a Pangaean monsoon-like system (Triassic, Middle Keuper, S. Germany). - Palaeogeography, Palaeoclimatology, Palaeoecology, 161, pp. 205-227.

Rigo, M., N. Preto, G. Roghi, F. Tateo, P. Mietto 2007: A rise in the Carbonate Compensation Depth of western Tethys in the Carnian (Late Triassic): Deep-water evidence for the Carnian Pluvial Event. - Palaeogeography, Palaeoclimatology, Palaeoecology, 246, pp. 188-205.

Şengör, A. M. C. 1984: The Cimmeride orogenic system and the tectonics of Eurasia. - Geological Society of America, Special Paper 195, pp. 1-82.

Şengör, A. M. C., Y. Yilmaz, I. Ketin 1980: Remnants of a pre-Late Jurassic ocean in northern Turkey: Fragments of Permian-Triassic Paleo-Tethys? - Geological Society of America, Bulletin, 91/10, pp. 599-609.

Smoot, J. P. 1991: Sedimentary facies and depositional environments of early Mesozoic Newark Supergroup basins, eastern North America. - Palaeogeography, Palaeoclimatology, Palaeoecology, 84, pp. 369-423.

Stampfli, G., G. Borel 2002: A plate-tectonic model for the Paleozoic and Mesozoic constrained by dynamic plate boundaries and restored synthetic oceanic isochrons. - Earth and Planetary Science Letters 196, pp. 17- 33.

Swanson, M. T. 1982: Preliminary model for an early transform history in central Atlantic rifting. Geology, 10, pp. 317-320.

Till, A. 1906: Der fossilführende Dogger von Villány (Südungarn). - Verhandlungen der kaiserlichköniglichen geologischen Reichsanstalt (1906), pp. 365-368.

Till, A. 1907: Herrn Dr. M. v. Pálfy zur Entgegnung bezüglich Villány. - Verhandlungen der kaiserlich-königlichen geologischen Reichsanstalt (1907), pp. 246-250. 
Till, A. 1910-1911: Die Ammonitenfauna des Kelloway von Villány (Ungarn). - Beiträge zur Paläontologie und Geologie Österreich-Ungarns und des Orients, 23, pp. 175-199, 251-272 (1910); 24, pp. 1-49 (1911).

Tollmann, A. 1987: Neue Wege in der Ostalpengeologie und die Beziehungen zum Ostmediterran. Mitteilungen der Österreichischen Geologischen Gesellschaft, 80, pp. 47-113.

Trümpy, R. 1988: A possible Jurassic-Cretaceous transform system in the Alps and the Carpathians. - Geological Society of America, Special Paper, 218, pp. 93-109.

Vadász, E. 1960: Magyarország földtana (Geology of Hungary). - Akadémiai Kiadó, Budapest, 646 p

Visscher, H., M. Van Houte, W. A. Brugman, R. J. Poort 1994: Rejection of a Carnian (Late Triassic) "pluvial event" in Europe. - Review of Palaeobotany and Palynology, 83/1-3, pp. 217-226.

Vollmer, T, W. Ricken, M. Weber, N. Tougiannidis, H.-G. Röhling, U. Hambach 2008: Orbital control on Upper Triassic Playa cycles of the Steinmergel-Keuper (Norian): A new concept for ancient playa cycle. - Palaeogeography, Palaeoclimatology, Palaeoecology, 267, pp. 1-16.

Vörös, A. 1972: A Villányi hegység alsó és középső júra képződményeinek üledékföldtani vizsgálata (Lower and Middle Jurassic formations of the Villány Mountains). - Földtani Közlöny, 102/1, pp. 12-28. (In Hungarian with English abstract)

Vörös, A. 1990: Villányi-hegység, Villány, Templom-hegy, felső-kőfejtő (Villány Mountains, Villány, Templom Hill, upper quarry). - In: Magyarország geológiai alapszelvényei (Geological keysections of Hungary). MÁFI, Budapest, 5 p.

Vörös, A. 1993: Jurassic microplate movements and brachiopod migrations in the western part of the Tethys. - Palaeogeography, Palaeoclimatology, Palaeoecology, 100, pp. 125-145.

Vörös, A. 2006: Mesozoic stratigraphy of the Inner West Carpathians. - In: Horváth, F, A. Galácz (Eds): The Carpathian-Pannonian Region. A review of Mesozoic-Cenozoic stratigraphy and tectonics. - Geologica Pannonica Special Publication 1, pp. 33-55, Hantken Press, Budapest, 624 p.

Vörös, A. 2010 in press: A villányi mezozoos rétegsor: visszatekintés új nézőpontból (The Mesozoic sedimentary sequences at Villány (southern Hungary). - Földtani Közlöny, 140/1, pp.

Vörös, A., L. Csontos 2006a: Mesozoic stratigraphy of the Tisza terrane. - In: Horváth, F, Galácz, A. (eds): The Carpathian-Pannonian Region. A review of Mesozoic-Cenozoic stratigraphy and tectonics. - Geologica Pannonica Special Publication 1, pp. 84-118, Hantken Press, Budapest, $624 \mathrm{p}$.

Vörös, A., L. Csontos 2006b: Palinspastic reconstruction. - In: Horváth, F, A. Galácz (Eds): The Carpathian-Pannonian Region. A review of Mesozoic-Cenozoic stratigraphy and tectonics. Geologica Pannonica Special Publication 1, pp. 477-501, Hantken Press, Budapest, 624 p.

Vörös, A., L. Kordos 2007: Villány, Templom-hegy. - In: Pálfy, J., Pazonyi, P. (Eds.): Ôslénytani kirándulások Magyarországon és Erdélyben (Palaeontological excursions in Hungary and Transylvania). - Hantken Kiadó, Budapest, pp. 162-171.

Walter, R. 1992: Geologie von Mitteleuropa. - Schweitzerbart'sche, Stuttgart, 561 p.

Wetzel, A., R. Allenbach, V. Allia 2003: Reactivated basement structures affecting the sedimentary facies in a tectonically "quiescent" epicontinental basin: an example from NW Switzerland. Sedimentary Geology, 157, pp. 153-172.

Wildi, W., H. Funk, B. Loup, E. Amato, P. Huggenberger 1989: Mesozoic subsidence history of the European marginal shelves of the Alpine Tethys (Helvetic realm, Swiss Plateau and Jura). Eclogae geologicae Helvetiae, 82/3, pp. 817-840.

Winterer E. L., A. Bosellini 1981: Subsidence and sedimentation on a Jurassic passive continental margin (Southern Alps, Italy). - American Association of Petroleum Geologists, Bulletin, 65, pp. 394-421.

Ziegler, P. 1988: Evolution of the Arctic-North Atlantic and the Western Tethys. - American Association of Petroleum Geologists, Memoir 43, Tulsa, Oklahoma 198 p. 